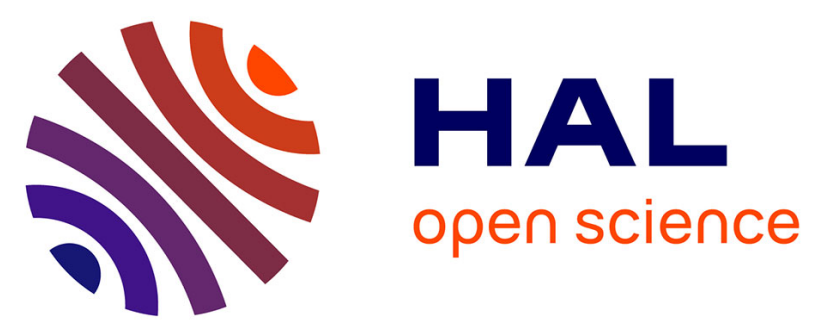

\title{
ISOLD: A New Highly Sensitive Interleukin Score for Intraocular Lymphoma Diagnosis
}

Myrto Costopoulos, Valérie Touitou, Jean-Louis Golmard, Adil Darugar, Sylvain Fisson, Patrick Bonnemye, Marie-Laure Le Lez, Carole Soussain, Nathalie Cassoux, Thierry Lamy, et al.

\section{To cite this version:}

Myrto Costopoulos, Valérie Touitou, Jean-Louis Golmard, Adil Darugar, Sylvain Fisson, et al.. ISOLD: A New Highly Sensitive Interleukin Score for Intraocular Lymphoma Diagnosis. Ophthalmology: Journal of The American Academy of Ophthalmology, 2016, 123 (7), pp.1626-1628. 10.1016/j.ophtha.2016.01.037 . hal-01290416

\section{HAL Id: hal-01290416 https://hal-univ-rennes1.archives-ouvertes.fr/hal-01290416}

Submitted on 18 Mar 2016

HAL is a multi-disciplinary open access archive for the deposit and dissemination of scientific research documents, whether they are published or not. The documents may come from teaching and research institutions in France or abroad, or from public or private research centers.
L'archive ouverte pluridisciplinaire HAL, est destinée au dépôt et à la diffusion de documents scientifiques de niveau recherche, publiés ou non, émanant des établissements d'enseignement et de recherche français ou étrangers, des laboratoires publics ou privés. 
ISOLD: a new highly sensitive Interleukin Score for intra-Ocular Lymphoma Diagnosis

Myrto Costopoulos, PharmD, ${ }^{1,2,3}$ Valérie Touitou, MD, PhD, ${ }^{2,4}$ Jean-Louis Golmard, MD, $\mathrm{PhD}^{2,5}$ Adil Darugar, MD, ${ }^{4}$ Sylvain Fisson, ${ }^{6}$ Patrick Bonnemye, ${ }^{1}$ Marie-Laure Le Lez, MD, ${ }^{7}$

Carole Soussain, MD, PhD ${ }^{8}$ Nathalie Cassoux, $\mathrm{MD}, \mathrm{PhD},{ }^{9}$ Thierry Lamy, MD, PhD, ${ }^{10,11}$

Phuc Le Hoang, MD PhD, ${ }^{2,4}$ Bahram Bodaghi, MD, PhD, ${ }^{2,4}$ Hélène Merle-Béral, MD, $\mathrm{PhD},{ }^{1,2,3}$ and Magali Le Garff-Tavernier, PharmD, $\mathrm{PhD}^{1,2,3}$

${ }^{1}$ Service d'Hématologie Biologique, Hôpital Pitié-Salpêtrière, AP-HP, Paris, France;

${ }^{2}$ Sorbonne Universités, UPMC, Paris 6, Paris, France;

${ }^{3}$ INSERM U1138, Programmed Cell Death and Physiopathology of Tumor Cells, Team 19,

Centre de Recherche des Cordeliers, Paris, France.

${ }^{4}$ Service d'Ophtalmologie, DHU View Maintain, Hôpital Pitié-Salpêtrière, Paris, France;

${ }^{5}$ Biostatistics Department, Hôpital Pitié-Salpêtrière, Paris, France;

${ }^{6}$ INSERM, UMRS951, Molecular Immunology and Innovative Biotherapies, Genethon, Evry,

${ }^{7}$ Service d'Ophtalmologie, Hôpital Bretonneau, Tours, France;

${ }^{8}$ Service d'Hématologie, Hôpital René Huguenin - Institut Curie, Saint-Cloud, France and

Collège de France, CNRS UMR 7241/INSERM U1050, Paris, France ;

${ }^{9}$ Service d'Ophtalmologie, Institut Curie, Paris, France;

${ }^{10}$ Service d'Hématologie, Hôpital Pontchaillou, Rennes, France;

${ }^{11}$ INSERM UMR 917, Department of Clinical Investigation, université de Rennes 1, Rennes,

France 

49

Corresponding author:

Myrto Costopoulos

Biological Hematology

Pitie-Salpetriere hospital

47-83 boulevard de l'hopital

75013 Paris

myrto.costopoulos@aphp.fr

Phone: 0033142160133

Fax: 0033142160161

Meeting Presentation: $19^{\text {th }}$ European Haematology Association Annual congress, Milan, June 2014

Financial Support: None

The authors have no financial conflict to declare.

Author Contributions:

Conception and design: Costopoulos, Merle-Beral, Le Garff-Tavernier

Analysis and interpretation: Costopoulos, Golmard, Bonnemye, Merle-Beral, Le Garff-

Tavernier

Data collection: Costopoulos, Darugar, Fisson, Bonnemye, Le Lez, Soussain, Cassoux, Lamy, Le Hoang, Bodaghi

Obtained funding: none

Overall responsibility: Costopoulos, Touitou, Merle-Beral, Le Garff-Tavernier 

tumors. Few is known about the pathogenesis. This is explained by the scarcity of patients and the tiny amount of ocular fluid sampled for biological analyses. In most cases, IOL is misdiagnosed as its clinical features can mimic other ocular conditions. To date, no independent biological tool is able to firmly diagnose IOL; the combination of cytological examination, immunochemistry, flow cytometry and molecular analysis is required. The determination of the interleukin (IL)-10 and IL-6 profile in ocular fluids appears to be a promising alternative. ${ }^{1,2}$ IL-10 increase is related to IOL and has immunomodulatory effects contributing to cell proliferation. Inflammatory conditions are associated with increased levels of IL-6. Reevaluation of the decisional thresholds is necessary for more efficient management.

Our study is retrospective, multicenter-case series, non-interventional, designed to assess the contribution of IL-10 and IL-6 quantifications in aqueous humor (AH) and vitreous to the IOL diagnosis.

Data were collected from patients undergoing eye fluid sampling, before any treatment, over 33 months in 23 French, Belgian and Swiss hospitals. The final diagnoses: IOL or other etiologies unrelated to malignant neoplasm (non-IOL) were obtained analyzing the clinical charts. A first cohort (training) was conducted to develop a diagnostic score. A total of 352 patients (398 $\mathrm{AH}$ and vitreous) were included in the training cohort. IOL was proven in 86 samples. 34 patients underwent both $\mathrm{AH}$ and vitreous sampling. A second cohort (validation) was carried out to test the score and included 93 patients (86 $\mathrm{AH}$ and 26 vitreous) exclusively recruited at La Pitie-Salpetriere Hospital over 15 months. The standalone validation cohort included IOL was diagnosed in 25 samples. Of the 93 patients, 16 gave both $\mathrm{AH}$ and vitreous samples. Bilateral IOL was documented in 5 patients. Overall, we evaluated 510 samples (445 patients) for IL-10 and IL-6 were measured using a sensitive Cytometric 
Bead Array ${ }^{\circledR}$ kit $\left(C B A\right.$, BD Biosciences $\left.{ }^{\mathrm{TM}}\right)$ on a FACSCantoII cytometer, with a limit of quantification of $2.5 \mathrm{pg} / \mathrm{ml}$. IL-10 and IL-6 quantifications were statistically analyzed and were compared with the definitive diagnosis.

It is widely accepted that high levels of IL-10 in ocular samples are an indirect marker of IOL. ${ }^{3}$ Nevertheless, no threshold is clearly established because of a "gray zone" making it difficult to differentiate IOL from non-IOL. To obtain higher sensitivity, the IL-10:IL-6 ratio previously reported is routinely calculated. ${ }^{4}$ In our study, despite the significant difference in the median IL-10:IL- 6 ratios between the 2 groups, a ratio $<1$ did not necessarily exclude the IOL diagnosis. These results clearly demonstrate that the ratio failed to detect some IOL (9 cases). Altogether, the use of the ratio is controversial and should only be considered for screening purposes. ${ }^{5}$

Thus, we developed a score: the Interleukin Score for intra-Ocular Lymphoma Diagnosis (ISOLD) coupled with a probability of "having an IOL". Patients were classified into four ordinal groups ranging from "certainly not IOL" to "certainly IOL". For AH, the ISOLD formula is: $-12.871+5.533 \times \log (\mathrm{IL}-10+1)-1.614 \times \log (\mathrm{IL}-6+1)$. For vitreous, the ISOLD formula is: $-12.208+4.648 \times \log (\mathrm{IL}-10+1)-1.669 \times \log (\mathrm{IL}-6+1)$. Each ISOLD value is associated with a probability calculated using the following function: $\operatorname{Probability}(\mathrm{IOL})=1 /(1+\exp (-\mathrm{ISOLD}))$.

ISOLD is associated with a probability of IOL and classifies patients in order to give easily interpretable results. In the first category, samples with scores <-4.6 (>99\% probability) are considered free of IOL. None of the IOL cases had a score <-4.6. Thus, ISOLD does not underdiagnose any IOL. On the other hand, a score >+4.6 (>99\% probability) is highly indicative of IOL. These two "certainty" clusters exclusively contain either non-IOL or IOL patients and represent $94 \%$ of all samples. In the intermediate zone, ranging from -4.6 to +4.6 , 
ISOLD has to be considered only when coupled with the probability. Between -4.6 and 0,12 non-IOL samples were associated with $<50 \%$ probability and were considered as wellclassified (table). The range 0 to +4.6 contained 6 IOL but also 2 non-IOL samples. These 2 samples came from patients with primary cerebral lymphoma who died before further investigation. ISOLD was powerful in correctly re-classifying the discrepancies obtained from the IL-10:IL-6 ratio. Thereby, these high probabilities are valuable and strongly guide the diagnosis.

The accuracy of ISOLD was confirmed in the validation cohort, with $92 \%$ of samples placed in the certainty zones. In the intermediate range, all IOL samples were properly shifted towards IOL diagnosis (ISOLD>0) (table). These findings confirm the strong predictive ability of ISOLD. Of note, 2 patients were referred for ocular toxoplasmosis, which is known to increase IL-6 and IL-10. On both cohorts, the sensitivity and specificity were respectively estimated at $93 \%$ and $95 \%$.

Cytology remains the main reliable criterion for IOL diagnosis. However, tumor cells are fragile and difficult to distinguish from reactive cells. Despite the rarity of IOL, we managed to conduct two large cohorts of 445 patients. For a more accurate diagnosis of IOL, we designed this ISOLD score. The real breakthrough is that the IL-10 and IL-6 values are not given as raw data but in association with a probability. This probability is a major revolutionary tool. In the 2 certainty zones of the score (probability>99\%), ISOLD correctly categorized $94 \%$ of the training cohort samples and $92 \%$ of the validation cohort samples. In both cohorts, we demonstrated that ISOLD is a powerful tool to diagnose $100 \%$ of IOL cases (probability $>50 \%$ ).

ISOLD was developed to strictly detect B-cell IOL as T and NK-cell IOL are very rare. However, we also report 5 cases of non B-cell IOL out of which, four were associated 
1451 Chan CC, Whitcup SM, Solomon D, et al. Interleukin-10 in the vitreous of patients 146

with high IL-10 levels, raising our suspicion regarding the capacity of NK-cells to secrete IL10.

Our study allowed us to build a novel strong diagnostic score based on easily measurable IL-10 and IL-6 levels. ISOLD is a simple yet powerful method with high sensitivity and specificity for detecting B-cell IOL. This innovative approach could be extremely useful to optimize patient's management.

\section{ACKNOWLEDGMENTS}

The authors thank the clinicians from all of the participating hospital centers in France, Belgium and Switzerland, in alphabetical order: Karine Augeul Meunier (Nantes), Edoardo Baglivo (Genève), Emmanuel Barreau (Bicêtre), Mpari Bedel (Amiens), Pierre Blaise (Liège), Jean-Louis Bourges (Paris), Frédéric Davi (Paris), Alice Degoumois (Caen), François Devin (Marseille), Bénédicte Dupas (Paris), Marie-Hélène Errera (Paris), Philippe Gohier (Angers), Julie Gueudry (Rouen), Jérome Guyomarch (Fort de France), Valérie Klinger (Mulhouse), Grégory Lazarian (Bobigny), Jean-Pierre Marolleau (Amiens), Hélène Massé (Rennes), Jean-Come Méniane (Fort de France), Bruno Mortemousque (Rennes), Frédéric Mouriaux (Caen), Pierre-Yves Robert (Limoges), Michel Ticchioni (Nice), Michel Weber (Nantes). The authors also thank Martine Brissard and Stéphanie Peuvion for valuable technical contributions.

\section{REFERENCES}

with primary intraocular lymphoma. Am J Ophthalmol 1995;120:671-3. 
1472 Cassoux N, Giron A, Bodaghi B, et al. Il-10 measurement in aqueous humor for 148 screening patients with suspicion of primary intraocular lymphoma. Invest Ophthalmol Vis 149 Sci 2007;48:3253-9.

1503 Merle-Beral H, Davi F, Cassoux N, et al. Biological diagnosis of primary intraocular 151 lymphoma. Br J Haematol 2004;124:469-73.

1524 Buggage RR, Whitcup SM, Nussenblatt RB, et al. Using interleukin 10 to interleukin 1536 ratio to distinguish primary intraocular lymphoma and uveitis. Invest Ophthalmol Vis Sci $154 \quad 1999 ; 40: 2462-3$.

1555 Akpek EK, Maca SM, Christen WG, et al. Elevated vitreous interleukin-10 level is not 156 diagnostic of intraocular-central nervous system lymphoma. Ophthalmology 1999;106:22911575. 